\title{
MORPHOLOGY AND MOLECULAR CHARACTERIZATION OF NEWLY ISOLATED MICROALGAE STRAIN CHLORELLA VOLUTIS LIPI13-WKT066 FROM WAKATOBI ISLANDS AND ITS POTENTIAL USE
}

\author{
Delicia Yunita Rahman ${ }^{1, *}$, Swastika Praharyawan ${ }^{1}$, Farizul Fadiyah ${ }^{1}$, Sapto Raharjo ${ }^{2}$, and \\ Dwi Susilaningsih ${ }^{1}$
}

${ }^{1}$ Reserach Center for Biotechnology, Indonesian Insitute of Sciences (LIPI), Indonesia

${ }^{2}$ Departement of Chemistry, Halu Oleo University, Indonesia

\begin{abstract}
Morphology and molecular characterization of microalgae isolated from Wakatobi Marine National Park was conducted. An understanding of the characteristics of morphology, molecular, as well as metabolites profile of the microalgae species is potentially useful for its future application. The primary aim of this study was to isolate, identify and characterize the microalgae strain isolated from Wakatobi Marine National Park labeled as LIPI13-WKT066 with the emphasis on the evaluation of amino acid content as a basis for its health application. Morphological observation under the microscope and molecular identification suggested that the microalgae strain of LIPI13-WKT066 belong to the strain under species of Chlorella volutis. Metabolite characterization of the microalgae strain showed that the content of protein (11.9\%), lipid (12.4\%) and carbohydrate $(4.7 \%)$ was in the regular range. Further analysis of its amino acid content revealed the potency of the microalgae strain to be used as antihypertensive agent.
\end{abstract}

Keywords: Chlorella volutis, Wakatobi islands, Marine environment, Health supplement.

*Corresponding author:

Cibinong Science Center, Jl. Raya Bogor Km. 46, Cibinong 16911, Indonesia

Tel. +62-21-8754587, Fax. +62-21-87754588

E-mail. firstauthor@gmail.com

\section{Introduction}

Microalgae are considered as the primary photosynthetic eukaryotes and are found all over the world in different habitat including fresh, marine, and brackish water (Lee, 2008). In many ecosystems, microalgae play critical roles in the primary producer, nutrients cycling, and oxygen production (Guedes and Malcata, 2012; Masojidek, 2013). Microalgae have engaged the attention of researcher worldwide due to their broad application in many areas. Its biomass contains high valuable primary and secondary metabolites such as protein, carbohydrates, lipid, pigment, antioxidant, vitamins and antibiotics which are beneficial for human health and attract commercial interest in the food industry (Chen and Vaidyanathan, 2013; Soto-Sierra et al., 2018). Several microalgae were reported to possess high protein content and many valuable compounds, including essential amino acids and fatty acids that cannot be synthesized by the human. Therefore they were potential to be used as a health food or dietary supplement (Milledge, 2011).

The many benefits possessed by microalgae do not make it immediately applicable in the real world. Some obstacles need to be overcome before the idea of microalgae industrialization become real, including the harvesting process, the effective method to obtain the active compounds, and the strain selection which is fast-growing and high biomass yield. The latter bottleneck can be solved through strain selection, with the native, indigenous strain which survives in local conditions (Rizza et al., 2017). Although microalgae have huge diversity, only a few of them were collected, identified, and available in the culture collection (Singh et al., 2015). Therefore, the isolation, identification, and 
characterization of local microalgae isolate would increase the gene bank data and provide the resources of microalgae strain for many applications in the local industry.

More than $60 \%$ of Indonesia territory is covered by water which not all of those areas had been explored yet. One of the unique marine environments also alleged to provide unique diversity of microalgae is Wakatobi marine national park. Wakatobi is an acronym for the four main islands of Wangi-Wangi, Kaledupa, Tomia, and Binongko that laid at the Southeastern tip of Sulawesi. This marine national park is famed for the diversity of its beautiful coral garden (Unsworth et al., 2010). Wakatobi has a diverse ecosystem inhabited by a wide range of organisms, such as plankton, coral reefs, fish, birds, turtles, and mangrove. Moreover, microorganisms from these islands have not been explored and utilized yet, including microalgae.

This research work is aiming at isolation, identification, and characterization of the microalgae strain from Wakatobi marine national park. In particular, an evaluation of the amino acid content as a basis for a health supplement.

\section{Materials and Methods}

\begin{abstract}
Algal strain and cultivation
A microalgae sample was collected from the pond in the Patuno resort Wangi-Wangi Island (Southeast Sulawesi) at S $05^{\circ} 14.886$ ' latitude and E 12335.200'. Single cell isolation techniques used to isolate microalgae strain under an inverted microscope (Olympus CX41) following Sekiguchi method (2013) with modification. The single cell was incubated in 24 wells plate and enriched with IMK medium. The cell colony then transfer to $20 \mathrm{~mL}$ of stock culture in a $100 \mathrm{~mL}$ Erlenmeyer at room temperature under continuous light. The algae were cultivated in a single batch in $500 \mathrm{~mL}$ working volume for 18 days.
\end{abstract}

\section{Morphological characteristic}

The microalgae were examined under a light microscope using brightfield and differential interference contrast. The microalgae strain was identified according to the morphological features. Morphological features of the isolated microalgae were recorded photographically 100x magnification using Olympus BX51 microscopy connected with a digital camera system.

\section{Molecular identification}

Total genomic DNA from microalgae cells was extracted using Vivantis GF-1 Plant DNA Extraction Kit. PCR amplification of the isolated DNA was performed on a thermocycler (Biorad) using SR1 and SR12 primers following Sekiguchi (2013) with modification. The reaction mixture contained 1 $\mu \mathrm{L}$ of DNA, $12.5 \mu \mathrm{L}$ Go Taq green master mix dNTP included, forward primer and reverse primer.

\section{Sequencing and phylogeny tree}

Amplified DNA was sequenced with the help of First Base (Singapore). The sequences obtained by the forward and reverse primers were inversed using BioEdit software (Alzohairy, 2011). Further sequence analysis of PCR product performed using the NCBIBlast (http://www.ncbi.nlm.nih.gov/BLAST/). The sequences were compared with the several microalgae sequences in the GenBank database using Blast. Multiple alignment of the sequences was done with the Mega X program (Kumar et al., 2018).

\section{Evaluation of growth and biomass composition}

The growth of isolated microalga was monitored by optical density at $800 \mathrm{~nm}$, the condition where the spectrum not effected to the absorption. The media used for cultivated the isolated strain was IMK (Daigo ltd.) in 500 $\mathrm{mL}$ working volume. After 18 days the biomass was harvested by centrifugation at $6000 \mathrm{rpm}$ for 10 minutes. The biomass was dried at $60^{\circ} \mathrm{C}$ for 24 hours. Total protein content examined by extract $100 \mathrm{mg}$ biomass with phosphate buffer $\mathrm{pH} \mathrm{7,} \mathrm{the} \mathrm{extract} \mathrm{then}$ mixed with Bradford reagent (Merck) and the spectrum absorption monitored by a spectrophotometer (Kruger, 2002). Total lipid content investigated following the method of Bligh and Dyer (1959). Total sugar content also examined using the phenol-sulfuric acid method with modification (Dubois et al., 1956).

\section{Determination of amino acid composition}

Microalgae protein extract in phosphate buffer $\mathrm{pH} 7$ was used for amino acid analysis. 
The sample was analyzed using Ultra Performance Liquid Chromatography (UPLC) commercially by PT. Saraswanti (Bogor, Indonesia). The column used for this analysis was ACCQ-Taq Ultra $\mathrm{C} 18$ at $49^{\circ} \mathrm{C}$ with gradient system as mobile phase. The result was detected with PDA at $260 \mathrm{~nm}$.
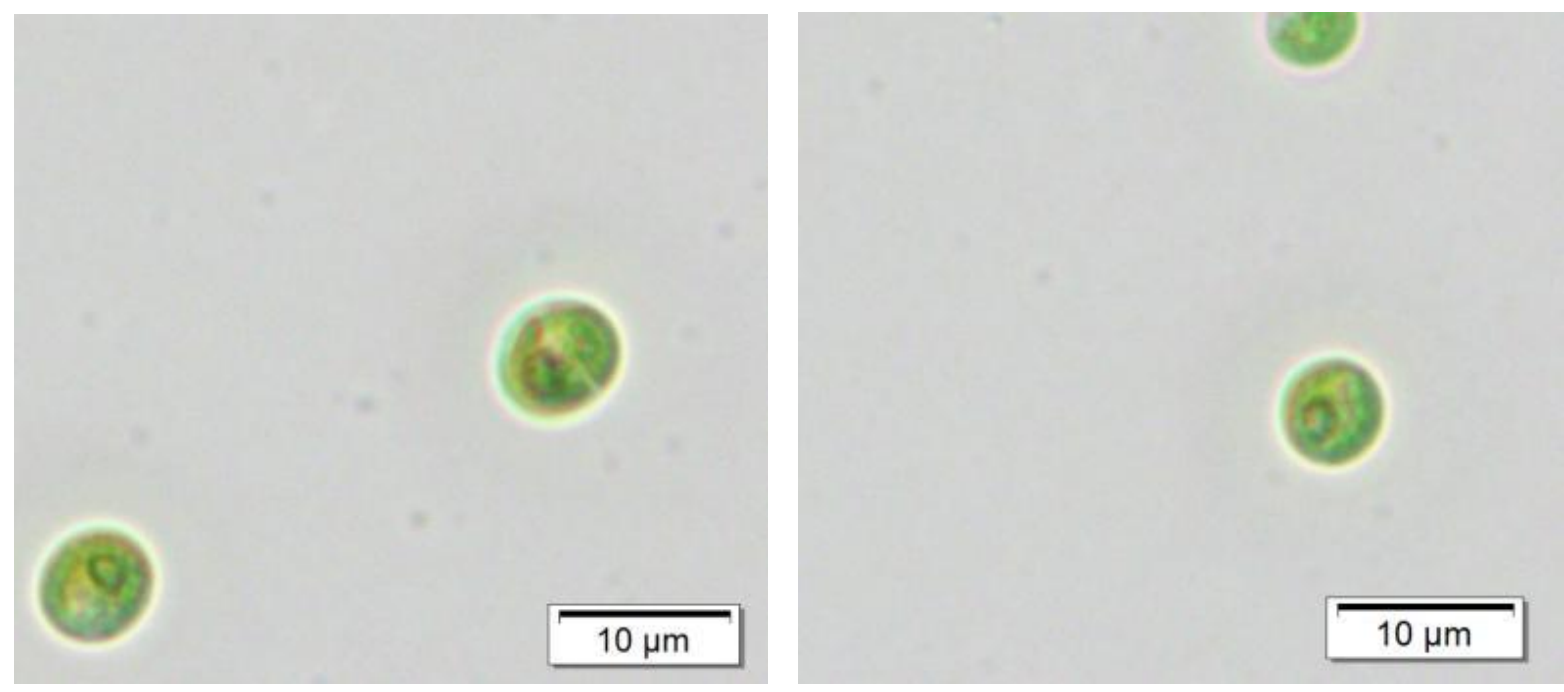

Figure 1. Microscopic overview of Chlorella volutis. LIPI13-WKT-066 with 1000x magnification. The diameter of the cell approximately 3-5 $\mu \mathrm{m}$. Scale bar: $10 \mu \mathrm{m}$.

\section{Results}

\section{Isolation of microalgae}

A microalgae strain was obtained from a pond near to the coast in Patuno area at Wangi-Wangi Island (Wakatobi Islands, Indonesia) and labeled as LIPI13-WKT-066. A single cell picks up techniques under an inverted microscope was used to isolate the desired microalgae. The single cell was washed several times in the fresh medium to ensure only one cell picked up. The growth single cell colony transferred to a new tube contained IMK medium and kept as a stock culture for further identification and analysis.

\section{Microalgae identification}

Morphology identification of LIPI13WKT066 was performed by observing the cell shape and diameter, the present of flagella and mucilage, and some feature inside the cells under a light microscope. The color of the culture was used in macroscopic observation of the isolated cell, which was bright green. The cell has round or spherical, solitaire, thick cell walls, pyrenoid inside the u-shape chloroplast with light green to yellowish color and diameter about 5-7 $\mu \mathrm{m}$ (Fig. 1). There is no flagella and no mucilage present around the cell. More extended observation showed the cell formed the auto-spore for regeneration. Based on consideration of morphology features, it leads the isolate to belong to Chlorophyta division without movement organelle and supposed to be the genus of Chlorella.

The molecular identification was carried out to prove the genus of the isolated microalgae strain as it was considered. The BLAST result of 18S DNA sequences showed that the isolated microalgae strain was moreclose to Chlorella sp. KMCC 185 with a similarity of $99 \%$ and the query cover of $99 \%$. The phylogeny showed the correlation of isolated strain with other species from Chlorella genus which has no flagella, no mucilage and eyespot (Fig. 2). Moreover, the morphology, physiology and molecular analysis of the isolated microalgae was related close to Chlorella volutis. 


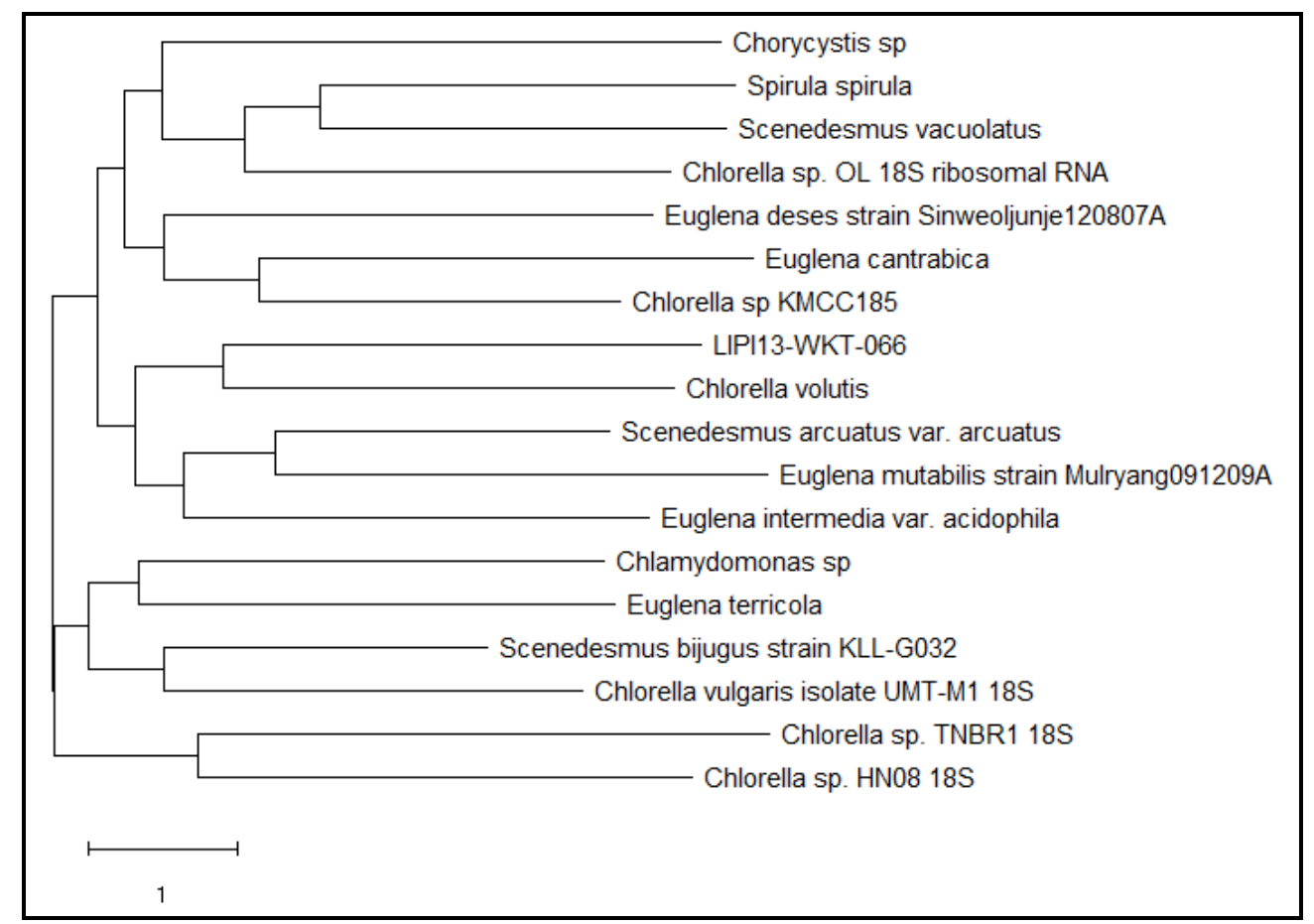

Figure 2. Phylogeny tree of Chlorella volutis LIPI13-WKT-066 using Neighbour-Joining method

\section{Growth and biomass chemical composition}

The growth of LIPI13-WKT-066 was monitored by a spectrophotometer at $680 \mathrm{~nm}$. The cultivation was carried out for 18 days, and it started the stationary stage in about day 12 (Fig. 3). After 18 days, the culture was harvested by centrifugation and dried the biomass. The dried biomass was approximately $1.4 \mathrm{~g} / \mathrm{L}$. The dried biomass then analyzed for protein, lipid, and carbohydrate content as showed in Table 1.

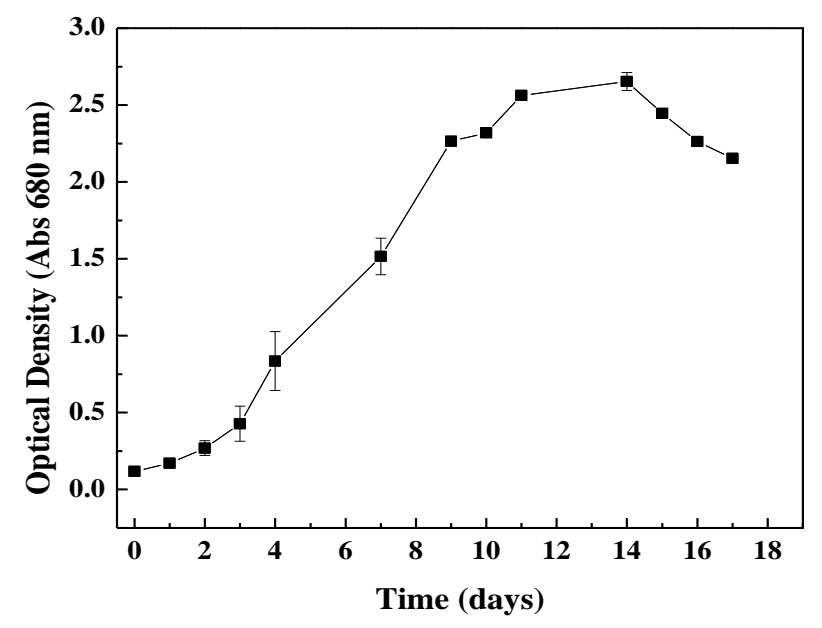

Figure 3. Growth curve of Chlorella volutis LIPI13-WKT-066 based on daily observation of the optical density at $680 \mathrm{~nm}$
Table 1. Chemical composition of microalgae macronutrients of Chlorella volutis LIPI13-WKT066.

\begin{tabular}{lccc}
\hline Parameter & $\begin{array}{c}\text { Dry } \\
\text { Biomass } \\
(\mathbf{m g})\end{array}$ & $\begin{array}{c}\text { Yield } \\
(\mathbf{m g})\end{array}$ & $\%$ \\
\hline Protein & 100 & 11.9 & 11.9 \\
Total Lipid & 100 & 12.4 & 12.4 \\
Carbohydrate & 100 & 4.7 & 4.7 \\
\hline
\end{tabular}

The amino acid content of the protein extract was analyzed using UPLC to evaluate the peptide that could be useful for the therapeutic application. Fifteen amino acids standard were used to identify the consisting amino acid in LIPI13-WKT-066 protein extract (Table 2). The LIP13-WKT-066 has high content of L-Alanine, L-Proline, and LGlutamic Acid $(150-200 \mathrm{mg} / \mathrm{kg})$, followed by Glycine, L-Arginine, L-Aspartic Acid, LSerine, and L-Threonine $(50-100 \mathrm{mg} / \mathrm{kg})$, and less content of L-Phenylalanine, LIsoleucine, L-Lysine $\mathrm{HCl}, \mathrm{L}-$ Tyrosine and $\mathrm{L}-$ Valine $(<50 \mathrm{mg} / \mathrm{kg})$. Based on the standard used in the analysis, the protein extract of LIPI13-WKT-066 lack of L-Histidine. 
Table 2. Amino acid profiles of protein extracted from Chlorella volutis LIPI13-WKT066.

\begin{tabular}{lc}
\hline Amino Acids & $\begin{array}{c}\text { Amino Acid Content of } \\
\text { Chlorella volutis } \\
\text { LIPI13-WKT066 } \\
\text { (mg/kg) }\end{array}$ \\
\hline Glicyne & 87.83 \\
L-Alanine & 193.81 \\
L-Arginine & 52.43 \\
L-Aspartic acid & 86.10 \\
L-Glutamic acid & 149.55 \\
L-Fenilalanin & 21.63 \\
L-Histidine & $n . d$. \\
L-Isoleusin & 28.91 \\
L-Leusin & 49.82 \\
L-Lysine Hcl & 33.45 \\
L-Proline & 181.36 \\
L-Serine & 57.90 \\
L-Threonine & 68.80 \\
L-Tyrosine & 37.14 \\
L-Valine & 49.83 \\
\hline
\end{tabular}

\section{Discussion}

Microalgae exist in all aquatic ecosystem, also in a harsh environment like hot spring, soil, and polluted water environment. In this study, the sampling point was at Patuno area in Wangi-Wangi island part of the Wakatobi marine national park. The location was chosen as it has a unique beach environment with several freshwater spring sprout out in the periphery beach-line. The sampling was done in August, in the dry season in Indonesia. The water temperature was about $28.8^{\circ} \mathrm{C}$ with $\mathrm{pH}$ of approximately 7.9. A microalgae strain was isolated and labeled as LIPI13-WKT-066. The single cell pick up techniques under an inverted microscope was performed to obtain the single cell microalgae. Anti-bacterial or anti-fungus was added to propagation culture to achieve an axenic microalgae culture. The microalgae LIPI13-WKT-066 was transferred into IMK medium from Daigo which has high content on sodium nitrate $(200 \mathrm{mg} / \mathrm{L})$ and a small amount of phosphate, ammonium, potassium, iron and also trace element. This medium enhanced of seawater nutrition to provide the nutrient for microalgae growth.

The morphology and molecular characterization of LIPI13-WKT-066 lead the identification to one of the chlorella species.
The genus of Chlorella names came from the Greek word Chloros and Latin suffix ella which means green and microscopic size. It is a unicellular microalgae found in fresh, marine or brackish water and has been existed on earth since 2.5 billion years ago (Safi et al., 2014). Chlorella genus has many species among it, and they are quite challenging to identify the species when only based on morphology data. In this study, microscopic observation of LIPI13-WKT-066 showed that the strain was unicellular and appeared to be solitary without a mucilaginous envelope (Fig. 1). The shape of the cell is spherical with almost similar size in diameter about 5-7 $\mu \mathrm{m}$. As typical in Chlorella genus (Yvonne and Tomas, 2000), this strain also does not have the flagella. The strain has a parietal, cup- or saucer-shaped chloroplast with ellipsoid or spherical pyrenoid. The strain multiplies asexually by formed autospore, in which is the most common asexual reproduction in algae.

Identification of microalgae strain is also supported by sequence-based phylogenetic analysis. A phylogenetic tree was constructed by comparing the published microalgae $18 \mathrm{~s}$ sequences from Genbank by using the Neighbour-Joining method in MEGA $X$ software (Kumar et al., 2018). Fig. 2, represents the Neighbour-Joining showing phylogenetic position of the strains and related taxa based on 18S rRNA sequence comparisons. In the phylogram analysis of the microalgae sequences ties the isolate LIPI13WKT-066 to Chlorella voluntis. There are many Chlorella species have been named since the first type of Chlorella vulgaris Beijerinck described in 1890, even though they are suffering from a shortage of morphological characteristics (Khaybullina et al., 2010; Bocks et al., 2011). The molecular identification could have to prove and convince the identification. The species of Chlorella volutis was introduced by Bocks et $a l$., in 2011. The etymology of "volutis" comes from Latin which means rolling. They described the Chlorella volutis as a solitary cell, planktonic or edaphic, globose 5-6.5 $\mu \mathrm{m}$, without mucilaginous. Reproduction by autospore, and the zoospore not attended. The differs of Chlorella volutis from other species of Chlorella genus by order of nucleotides in ITS- 1 and ITS- 2 and the barcoding signatures.

The growth curve of LIPI13-WKT-066 in IMK medium was monitored by optical 
density at $680 \mathrm{~nm}$, in which the wavelength of chlorophyll-protein complexes, from the inoculation day to the next 18 days (Fig. 3) growth rate with initial absorbance of 0.1 showed a lag phase (2 days) followed by an exponential phase extending till $9^{\text {th }}$ days, a slower late log phase, and a stationary phase. The growth pattern of microalgae strain is in accordance to Abou-Shanab et al., (2011) who described the growth rate analysis.

Under our experiment growth condition, Chlorella volutis LIPI13-WKT-066 has $11.9 \%$ protein, $12.4 \%$ lipid, and $4.7 \%$ carbohydrate. According to the literature, the content of protein of mature Chlorella genus is about 26 $-70 \%$ of dry biomass weight, while the lipid content 5-40\%, and carbohydrate content approximately reach $12-55 \%$ (Safi et al., 2014). The nutrient composition in the culture medium and the condition of cultivation could make the variation of the chemical content of biomass (da Silva Gorgônio et al., 2013). Yeh and Chang (2012) also reported that the different condition in the microalgae cultivation could cause different lipid content and composition.

The nutritional quality of protein is determined by its amino acid profiles (Safi et al., 2013). The species from Chlorella genus synthesize essential and non-essential amino acid. Moreover, for example the amino acid profile of C. vulgaris compares favourably and even better with the standard profile for human nutrition suggested by WHO and FAO (Safi et al., 2014). According to Table 2, the most abundant amino acid in Chlorella volutis LIPI13-WKT-066 is L-Alanine (193 mg/kg) following by L-Proline (181.36\%) and LGlutamic acid (149.55). The protein extract of Chlorella volutis LIPI13-WKT-066 contains almost all amino acid that used as the standard, except L-Histidine. The amino acid composition of each species among Chlorella species might be different as it depends on the metabolism of the species and also on the cultivation conditions.

Protein or peptide fraction could be used as a therapeutic agent. One interesting application for high content protein microalgae is antihypertensive agents. According to Setsuna and Chen (2001), peptide fractions from $C$. vulgaris gave a positive effect to act as antihypertensive. Thus, the amino acid sequences of the peptides were Ile-Val-Val-Glu, Ala-PheLeu, Phe-Ala-Leu, Ala-Glu-Leu, and Val-Val-
Pro-Pro-Ala. Almost all of the peptides that have higher antihypertensive potential had a proline, phenylalanine, valine, and glutamic acid. Perhaps the abundance of amino acid that mentioned above in purified peptide might explain the exhibited potency of its antihypertensive activity (Setsuna and Chen, 2001; Shieh et al., 2009).

This study highlighted the isolation and characterization of microalgae strain isolated from Patuno area at Wakatobi marine national park that lead to the identification of the Chlorella volutis, one of the chlorella genus. The algae has varied amino acid content with the highest is Alanine followed by Proline and Glutamic acid. Those abundance amino acids were related to the composition of peptide that acts antihypertensive.

\section{Acknowledgements}

The research was supported by 'Competitives Research Program LIPI' in 2015 fiscal year. We thank 'Wakatobi National Park' team for their assistance during sampling and environment assessment. We also appreciate 'Wakatobi Marine Biosphere Region' for allowing us to do the research in the area.

\section{References}

Abou-Shanab, R.A.I., Matter, I.A., Kim, S-N., Oh, Y-K., Choi, J., Jeon, B-H. (2011). Characterization and identification of lipidproducing microalgae species isolated from a freshwater lake. Biomass and Bioenergy, 35, 3079-3085.

Alzohairy, A.M. (2011). BioEdit: An importat software for molecular biology. GERF Bulletin of Biosciences, 2, 60-61.

Bligh, E.G., Dyer, W.B. (1959). A rapid method of total lipid extraction and purification. Canadian Journal of Biochemistry and Physiology, 37, 911-917.

Bock, C., Krienitz, L., Pröschold, T. (2011). Taxonomic reassessment of the genus Chlorella (Trebouxiphyceae) using molecular signatures (barcodes), including description of seven new species. Fottea, 11, 293-312.

Chen, Y., Vaidyanathan, S. (2013). Simultaneous assay of pigments, carbohydrates, proteins and lipids in microalgae. Analytica Chimica Acta, 776, 31-40. 
Da Silva Gorgônio, C.M., Aranda, D.A.G., Couri, S. (2013). Morphological and chemical aspects of Chlorella pyrenoidosa, Dunaliella tertiolecta, Isocrysis galbana and Tetraselmis gracilis microalgae. Natural Science, 5, 783-791.

Dubois, M., Gilles, K.A., Hamilton J.K., Rebers P.A., Smith, F. (1956). Colorometric methods for determination of sugars and related substances. Analytical Chemistry, 28, 350-356.

Guedes, A.C., Malcata, F.X. (2012). Nutritional value and uses of microalgae in aquaculture, Aquaculture, S. Zainal Muchlisin (Ed). China: InTech. 59-78.

Khaybullina, L.S., Gaysina, L.A., Johansen, J.R., Krautova, M. (2010). Examination of the terrestrial algae of the Great Smoky Mountains National Park, USA. Fottea, 10, 201-215.

Kruger, N.J. (2002). The Bradford method for protein quantification, The Protein Protocols Handbook, $2^{\text {nd }}$ Edition. JM Walker (Ed). Totowa, New Jersey: Humana Press Inc. 15-21.

Kumar, S., Stecher, G., Li, M., Knyaz, C., Tamura, K. (2018). MEGA X: Molecular evolutionary genetics analysis across computibg platform. Molecular Biological Evolution, 35, 1547-1549.

Lee, R.E. (2008). Phycology. New York: Cambridge University Press.

Masojídek, J., Torzillo, G., Koblížek, M. (2013). Photosynthesis in Microalgae, Handbook of Microalgae culture: Applied Phycology and Biotechnology, A. Richmond and Q. Hu (Ed). John Wiley \& Sons, Ltd, 21-36.

Milledge, J.J. (2011). Commercial application of microalgae other than as biofuels: a brief review. Review of Environmental Science and Biotechnology, 10, 31-41.

Rizza, L.S., Smachetti, M.E.S., Nascimento, M.D., Salerno, G.L., Curatti, L. (2017). Bioprospecting for native microalgae as an alternative source of sugars for the production of bioethanol. Algal Research, 22, 140-147.

Safi, C., Charton, M., Pignolet, O., Pontalier, P-Y., Vaca-Garcia, C. (2013). Evaluation of the protein quality of Porphyridium cruentum. Journal of Applied Phycology, 25, 497-501.

Safi, C., Zebib, B., Merah, O., Pontalier, P-Y., Vaca-Garcia, C. (2014). Morphology, composition, production, processing and application of Chlorella vulgaris: A review. Renewable and Sustainable Energy Reviews, 35, 265-278.

Sekiguchi, H. (2013). Collection, screening, and preservation for oil producing algae. Algal Oil, 9, 177-196.

Setsuno, K., Chen, J.R. (2001). Identification of Antihypertensive Peptides from Peptic Digest of Two Microalgae, Chlorella vulgaris and Spirulina platensis. Marine Biotechnology, 3, 305-309.

Shieh, I-C., Fang, T.J., Wu, T-K. (2009). Isolation and characterization of a novel angiostensin I-converting enzyme (ACE) inhibitory peptide from algae protein waste. Food Chemistry, 115, 279-284.

Singh, P., Gupta, S.K., Guldhe, A., Rawat, I., Bux, F. (2015). Microalgae isolation and basic culturing technique. In Kim SK (ed). Handbook of marine microalgae. Elsevier. pp. 43-54.

Soto-Sierra, L., Stoykova, P., Nikolov, Z.L. (2018). Extraction and fractionation of microalgae-based protein products. Algal Research, 36, 175-192.

Unsworth, R., Clifton, J., Smith, D. (2010). Marine research and conservation in the coral triangle: the Wakatobi National Park. Nova Science. 1-258.

Yvonne, N., Tomas, K. (2000). Cell wall development, microfibril and pyrenoid structure in type strains of Chlorella vulgaris, $C$. kessleri, C. sorokiniana compared with $C$. luteoviridis (Trebouxiophyceae, Chlorophyta). Archiv fur Hydrobiologie, 100, 96-105.

Yeh, K.L., Chang, J.S. (2012). Effects of cultivation conditions and media composition on cell growth and lipid productivity of indigenous microalga Chlorella vulgaris ESP-31. Bioresource Technology, 105, 120-7. 